\title{
Postgraduate Students' Perception of Creativity in the Research Process
}

MOJCA JURIŠEVIČ ${ }^{1}$

$\approx$ The purpose of the research was, with the aid of a short questionnaire, to determine how postgraduate students $(\mathrm{N}=32)$ perceive the opportunities for creative research in general, and how they perceive creativity in the preparation of their own research work in particular. Descriptive analysis shows that students (1) perceive a positive study-research climate that encourages creative processes (independence, motivation, intellectual challenges), (2) judge that researchers have numerous opportunities for creative work in the various phases of research and (3) evaluate themselves as highly creative individuals in everyday life. Students perceive themselves as being at their most creative in the definition of the research problem, which they mainly identify with the use of personal strategies (work experience) and take various lengths of time to form, typically up to one year. The most difficult problem in this regard is represented by giving meaning to the problem (breadth, depth, specificity, application). Amongst the perceived encouragement with which mentors motivate students for creative research the most frequent is less directive general guidance in study and research. On the basis of the presented findings, guidelines are suggested for the more effective encouragement of creative research in postgraduate students.

Key words: Postgraduate study, Research, Research problem, Scientific creativity. 
Through phylogeny, creativity is the central motor of human development in various areas, from the solving of everyday life problems through the arts and economics to science, which with its achievements contributes to sustainable development - economic, social and environmental (Beghetto and Kaufman, 2007; Collins, 2007; Runco, 2004; Sawyer, 2006; Stehr, 1994; Sternberg and Lubard, 1999; Weisberg, 1993). In his resounding work Antropologija ustvarjalnosti (The Anthropology of Creativity), Makarovič (2003) asserts that creativity is "...the highest human manifestation, the very highest expression of humanity, which as such presupposes the entirety of human reality." (p. 47). Today, we generally understand creativity as a psychological phenomenal that manifests itself in the form of the production of ideas - new and unusual ideas, but ideas that are effective and useful for particular purposes (Amabile, 1996; Ochse, 1990; Sternberg, 2003), with regard to which the ethical dimension of creative ideas is increasingly taken into account (Cropley, 2009). Defined in this way, creativity is closely linked with the concept of divergent thinking, as initially developed in the area of researching creativity by Guilford (1950). Divergent thinking is defined as the basis for creativity and is determined by four attributes: (1) fluency - the ability to quickly produce a large number of ideas or solutions to a particular problem, (2) flexibility - the ability to produce various ideas or to simultaneously take into account various aspects in problem solving, (3) originality - the ability to produce new and unusual (rare) ideas and (4) elaboration - the ability to reflect deeply on ideas and to work ideas out in detail. Although in his work Guilford does not explicitly emphasise the applicative value of ideas, this value is particularly important. Not all that is new is creative; we can only consider creativity in cases where ideas fulfil exterior criteria of individual and social wellbeing (Cropley, 2009; Pečjak, 1987). Furnham and Bachtiar (2008) emphasise that, due to its multi-component nature and complexity, creativity is difficult to define precisely, as well as being difficult to measure. On the basis of more than 60 definitions of creativity they determine that the most important components for defining creativity are cognitive ability, personality traits, cognitive styles and motivation. Similar conclusions are arrived at by Makel and Plucker (2008), who synthetically combine the authors of various definitions of creativity into three large groups: (1) psychometric, who attempt to understand creativity from the point of view of the structure (of the various components) of creativity, (2) developmental, who explain creativity from the point of view of developmental dynamics and 
(3) contextual, who emphasise the sociocultural aspect of understanding creativity, in the sense of the various factors that influence creativity (cf. Amabile, 1996; Csikszentmihalyi, 1999; Gardner, 1993; Hemlin, Allwood \& Martin, 2004; Sternberg \& Lubard; 1996; Torrance, 2004; Urdan, 2007). In view of the above, for the purpose of understanding creativity in the continuation of the present article it seems sensible to accept an operational definition that combines all of the aspects of creativity mentioned so far: "Creativity is the interaction among aptitude, process, and environment by which an individual or group produces a perceptible product that is both novel and useful as defined within a social context." (Plucker, Beghetto \& Dow, 2004, p. 90).

\section{Creativity in scientific research}

Craig (1990) emphasises four conditions for a successful career in science: (1) knowledge, (2) technical skills, (3) communication skills and (4) originality or creativity. The latter is of particular importance, as the problems of scientific research are complex and multivariate, as well as being oriented towards innovative solutions. Amabile, Conti, Coon, Lazenby and Herron (1996) emphasise that "every innovation begins with a creative idea" (p. 1154) and that creativity can be thought of as the creation of new meaningful ideas, while innovativeness is the transformation of these ideas into useful new products, with both processes arising as a function of the interaction between the individual and his or her environment. Similarly, Sawyer (2006) finds that a common characteristic of the most influential and most important scientists is their inexhaustible creativity, a fact that can be well explained from the sociocultural point of view; the most important scientific discoveries arise through the high level cooperation of scientific teams, which demonstrates that "scientific creativity is both a psychological and social process" (p. 278; see also L'Abate, DeGiacomo, Capitelli \& Longo, 2009; Miller, 2000). In his thinking, Simonton (2003) combines both approaches to understanding creativity: the point of view of the personality traits of creative scientists and that of the creative processes that take place during research. He explains scientific creativity as a stochastic structure in which a third element is also integrated: the creative product (creative ideas). Only the latter can enable a complete insight into the phenomenon of creativity, while the first two provide only a partial picture, as they are simultaneously determined and limited by the research paradigm in the background. Studying personality traits follows the tradition of the psychology of individual differences 
and correlational research, whereas studying processes takes place more in the domain of cognitive psychology and is experimentally based. Simonton (2003) explains the aforementioned partialness with the expression "not to see the forest for the trees" (p. 490), and as a way forward suggests research of real creative behaviour. According to his theory, creative achievements in scientific research come about as events with a low probability - in line with Poisson distribution; quality creative products are a probability product of the quantity of products, which in the end means that the probability of the phenomenon of a high quality creative product is greatest in the most fertile period in the life of the researcher and of the scientific community to which he or she belongs. Simonton's model of stochastic combinatorics confirms the findings of a study undertaken by Adelson (2003), in which the author interviewed eight scientists - Franklin Institute prizewinners for 2002 - and on the basis of their stories worked out a very dynamic picture of the concept of scientific creativity. Amongst her most important findings, one that stands out is the scientists' selfimage of extreme diligence; in spite of their extraordinary creative scientific achievements, the interviewees do not perceive themselves as possessing above average talent and creativity, but rather report a high level of involvement and persistence, as well as personal engagement in scientific work, while stating the main reason for their scientific success as their analytical abilities (not intuition, A/N), high intrinsic motivation, positive self-concept and the absence of competitive pressures. Alongside Pasteur's supposition that "chance favours the prepared mind", these findings confirm Simonton's understanding of scientific creativity.

Heinze, Shapira, Rogers and Senker (2009) explain that, as in other fields, creativity in scientific research is defined as "knowledge and capabilities that are new, original, surprising, and useful" (p. 611), to which Charyton and Snelbecker (2007) add the observation that scientific creativity differs from artistic creativity, for instance, primarily in its special emphasis on the attribute of function or applicative value (usefulness); furthermore, more so that in other fields, scientific and creative achievements and innovations are very precisely evaluated on the basis of highly developed scientific criteria, such as publicity, validity and originality (Simonton, 2004; Soler, 2007). 


\section{Types of scientific creativity}

Heinze, Shapira, Rogers and Senker (2009) proposed a typology of scientific research creativity that emphasises the functional characteristics of creative novelties and is linked with the various phases of the research process: defining the research problem, planning the research method, gathering data, analysis and/or preparation of the research report. They assume five different kinds of research creativity, which are typically interlinked (Heinze et al., 2007, p. 132):

- $\quad$ Formulation of a new idea (or a set of new ideas) that opens up a new cognitive frame or brings theoretical claims to a new level of sophistication (e.g., Einstein's Theory of Specific Relativity).

- Discovery of new empirical phenomena that stimulate new theorising (e.g., Darwin's Theory of Evolution).

- Development of a new methodology, by means of which theoretical problems can be empirically tested (e.g., Spearman's Theory of Mental Abilities).

- Invention of novel instruments that open up new research perspectives and research domains. (e.g., Binnig and Rohrer's Nanotechnology).

- New synthesis of formerly dispersed existing ideas into general theoretical laws enabling analyses of diverse phenomena within a common cognitive frame (e.g., Bertalanffy's General Systems Theory).

\section{The development of the creative idea in scientific research}

Wallas (1926, cited in Cropley, 2009) explains the development of the creative idea or product with the aid of a four-level development model that is today regarded as a classic. In the first phase, the individual first becomes familiar with the idea (information); there follows an incubation phase (the idea "prepares" itself), while in the phase of illumination the solution (suddenly) arises, which the individual then verifiers in the concluding phase (verification). From the point of view of the sociocultural paradigm, which emphasises the role of the social environment and context for creativity, Wallace's model becomes too narrow; therefore, Cropley (2009) adds two more phases: the phase of communicating the idea to other people and of their 
feedback (evaluation) regarding the effectiveness of the idea. In addition to this, Cropley includes another introductory phase in the model; he calls this the phase of preparation, in which the individual becomes aware of the problem and develops a purpose. Cropley's model of the development of the creative idea is shown in Table 1. A familiarity with this model is important both for understanding the dynamics of creativity as a stochastic structure in Simonton's sense and for encouraging creative thinking in various areas, as with a precise knowledge of the described characteristics we can select individual activities for encouraging specific processes in a more strategic way.

Table 1. Creative processes, traits and motives in the phases of the production of novelty (Cropley, 2009, p. 73)

\begin{tabular}{|c|c|c|c|c|c|}
\hline Phase & Process & Results & Motivation & Personality & Feelings \\
\hline Preparation & $\begin{array}{l}\text { Identifying } \\
\text { problem } \\
\text { Setting goals } \\
\text { Convergent } \\
\text { thinking }\end{array}$ & $\begin{array}{l}\text { Initial } \\
\text { activity } \\
\text { General } \\
\text { knowledge } \\
\text { Special } \\
\text { knowledge } \\
\end{array}$ & $\begin{array}{l}\text { Problem- } \\
\text { solving drive } \\
\text { (intrinsic) } \\
\text { Hope of gain } \\
\text { (extrinsic) }\end{array}$ & $\begin{array}{l}\text { Critical } \\
\text { attitude } \\
\text { Optimism }\end{array}$ & \\
\hline Information & $\begin{array}{l}\text { Perceiving } \\
\text { Learning } \\
\text { Remembering } \\
\text { Convergent } \\
\text { thinking }\end{array}$ & $\begin{array}{l}\text { Focused } \\
\text { special } \\
\text { knowledge } \\
\text { Rich supply } \\
\text { of cognitive } \\
\text { elements }\end{array}$ & $\begin{array}{l}\text { Curiosity } \\
\text { Preference } \\
\text { for } \\
\text { complexity } \\
\text { Willingness } \\
\text { to work hard } \\
\text { Hope of gain }\end{array}$ & $\begin{array}{l}\text { Knowledge } \\
\text { ability } \\
\text { Willingness } \\
\text { to judge and } \\
\text { select }\end{array}$ & $\begin{array}{l}\text { Dissatis- } \\
\text { faction }\end{array}$ \\
\hline Incubation & $\begin{array}{l}\text { Divergent } \\
\text { thinking } \\
\text { Making } \\
\text { associations } \\
\text { Biociation } \\
\text { Building } \\
\text { networks } \\
\end{array}$ & $\begin{array}{l}\text { Configura- } \\
\text { tions }\end{array}$ & $\begin{array}{l}\text { Freedom } \\
\text { from } \\
\text { constraints } \\
\text { Tolerance for } \\
\text { ambiguity }\end{array}$ & $\begin{array}{l}\text { Relaxedness } \\
\text { Acceptance } \\
\text { of fantasy } \\
\text { Non- } \\
\text { conformity } \\
\text { Adventuro- } \\
\text { usness }\end{array}$ & $\begin{array}{l}\text { Interest } \\
\text { Curiosity }\end{array}$ \\
\hline Illumination & $\begin{array}{l}\text { Recognising a } \\
\text { promising new } \\
\text { configuration }\end{array}$ & $\begin{array}{l}\text { Novel } \\
\text { configura- } \\
\text { tions } \\
\end{array}$ & $\begin{array}{l}\text { Intuition } \\
\text { Reduction of } \\
\text { tension }\end{array}$ & $\begin{array}{l}\text { Sensitivity } \\
\text { Openness } \\
\text { Flexibility } \\
\end{array}$ & $\begin{array}{l}\text { Determin- } \\
\text { ation } \\
\text { Fascination }\end{array}$ \\
\hline Verification & $\begin{array}{l}\text { Checking } \\
\text { relevance and } \\
\text { effectiveness } \\
\text { of novel } \\
\text { configuration }\end{array}$ & $\begin{array}{l}\text { Appropriate } \\
\text { solution } \\
\text { displaying } \\
\text { relevance } \\
\text { and } \\
\text { effectiveness }\end{array}$ & $\begin{array}{l}\text { Desire for } \\
\text { closure } \\
\text { Desire to } \\
\text { achieve } \\
\text { quality }\end{array}$ & $\begin{array}{l}\text { Hard-nosed } \\
\text { sense of } \\
\text { reality } \\
\text { Self- } \\
\text { criticism }\end{array}$ & Excitement \\
\hline
\end{tabular}




\begin{tabular}{|c|c|c|c|c|c|}
\hline $\begin{array}{l}\text { Communi- } \\
\text { cation }\end{array}$ & $\begin{array}{l}\text { Achieving } \\
\text { closure } \\
\text { Gaining } \\
\text { feedback }\end{array}$ & $\begin{array}{l}\text { Workable } \\
\text { product } \\
\text { capable of } \\
\text { being made } \\
\text { known to } \\
\text { others }\end{array}$ & $\begin{array}{l}\text { Desire for } \\
\text { recognition } \\
\text { (intrinsic) } \\
\text { Desire for } \\
\text { acclaim } \\
\text { or reward } \\
\text { (extrinsic) }\end{array}$ & $\begin{array}{l}\text { Self- } \\
\text { confidence } \\
\text { Autonomy } \\
\text { Courage } \\
\text { of one's } \\
\text { convictions }\end{array}$ & $\begin{array}{l}\text { Anticipat- } \\
\text { ion } \\
\text { Hope } \\
\text { Fear }\end{array}$ \\
\hline Validation & $\begin{array}{l}\text { Judging } \\
\text { relevance and } \\
\text { effectiveness }\end{array}$ & $\begin{array}{l}\text { Product } \\
\text { acclaimed } \\
\text { by relevant } \\
\text { judge (e.g., } \\
\text { teacher) }\end{array}$ & $\begin{array}{l}\text { Desire for } \\
\text { acclaim } \\
\text { Mastery } \\
\text { drive }\end{array}$ & $\begin{array}{l}\text { Toughness } \\
\text { Flexibility }\end{array}$ & Elation \\
\hline
\end{tabular}

Leong and Pfaltzgraff (1996) explain that "finding" a genuine research idea is an important creative moment in research work. Although conditioned primarily by the researcher's personal interests, this process can be made easier if the researcher approaches it strategically, on the basis of knowledge and with the combined application of various searching strategies; amongst these strategies the author emphasises (1) personal strategies, on the basis of personal experience and observation (personal preferences, previous work, work environment, media), (2) interpersonal strategies, on the basis of communication with reference individuals or groups (mentors, professors, researchers, colleagues, participation in various scientific research meetings), (3) the strategic use of printed sources, on the basis of individual study of the literature (books, journals, various types of reports) and (4) the strategic use of electronic sources of information (ICT), on the basis of various databases and other Internet sources.

\section{Purpose of the research}

In the research we were interested in how postgraduate students perceive the scientific research community, that is, the environment for creative research, and, just as importantly, how they perceive their own competence for creative research within the framework of postgraduate study. Zgaga (2007) explains that with the introduction of new (doctoral) programmes within the framework of Bologna study there has been a significant change in the "architecture" of study. Although certain weaknesses are already evident in the new system (e.g., consequences of the large number enrolments) specific advantages are also clear, in particular originality in research and the encouragement of high quality new (interdisciplinary) knowledge. Special emphasis has also been placed on the role of the mentor, the formation of research 
communities and the purpose of education on the doctoral level, which no longer simply serves the needs of the university but rather focuses on the needs of society in general. It is possible to follow and encourage these advantages with the goal of sustainable development.

In the explorative research described in the continuation, we set four research questions: (1) How do postgraduate students perceive a research environment or climate that encourages creativity? (2) How do students perceive the opportunities for creative research? (3) How do students evaluate their own achievements in the research process? and (4) What kind of mentor encouragement for creative study do the students perceive?

\section{Method}

\section{Participants}

32 first year postgraduate students at the Faculty of Education of the University of Ljubljana during the 2009/2010 academic year participated in the research (43\%). They were masters students studying Preschool Education, and Supervision, Personal and Organisational Counselling, as well as doctoral students of Teacher Education and Educational Sciences ${ }^{1}$. At the time of the research, the subjects tested had an average age of 33.1 years ( $\mathrm{SD}=6.6$ years), and the sample included 31 woman and 1 man.

\section{Instrument and procedure}

The participants filled out a short combined questionnaire that was designed for the purpose of the study. The questions related to how the postgraduate students perceived creativity in research. There were five open questions and three questions that students responded to on an attached assessment scale. The questions were:

1) On a seven-level scale (from 7 - completely true, to 1 certainly not true) assess how you personally experience the various aspects of your research work within the framework of postgraduate study.

1 We included students from both the masters and doctoral study programmes (second and third Bologna cycles) together in the same sample, as in preliminary analysis we did not find significant differences between the answers of the participating students. They were all Bologna first generation students at the Faculty of Education, University of Ljubljana. 
2) On a five-level scale (from 5 - very creative, to 1 - completely uncreative) assess how creative, in your personal opinion, researchers can be in the individual phases of research work.

3) On a five-level scale (from 5 - very creative, to 1 - completely uncreative) assess your own creativity in general in life.

4) In your personal opinion, where does the central originality of your research work lie?

5) Describe as precisely as possible how you identified and defined your research problem, that is, what led you to your research idea.

6) How much time did you need to define your research problem?

7) What difficulties did you face while defining your research problem?

8) Describe in the most concrete terms possible how your mentor at the faculty has until now encouraged you to engage in original research work or to seek innovative research solutions.

For the sake of economy, the survey was executed through email and was completely voluntary. It took place at the end of the second semester of study (July 2010), when the students had already acquired basic study-research experience and had begun to prepare the theses for their research.

The data was analysed descriptively (basic statistics were calculated) and qualitatively (the content of the responses to the questions was analysed).

\section{Results}

\section{Experience of the climate of research work in postgraduate study}

On a seven-level assessment scale, students assessed nineteen components of climate as they perceived it during their research work. These components were included in the question on the basis of findings by authors who have researched work climate connected with creative processes (Amabile, 1996; Amabile, Conti, Coon, Lazenby \& Herron, 1996; Ekvall, 1996; Hunter, Bedell \& Mumford, 2007). In general, students assess the motivating components of climate highly $\left(\mathrm{M}_{\text {average }}=5.65\right)$ and perceived an average presence of the demotivating 
components of climate $\left(\mathrm{M}_{\text {average }}=3.23\right)$. The average arithmetic means and standard deviations for the individual components are shown in Table 2. In their research work, students most intensely experience independence $(M=6.22, S D=0.91)$, motivation $(M=6.06, S D=1.01)$ and intellectual challenges enabled by research $(\mathrm{M}=6.00, \mathrm{SD}=0.92)$. At the other end of the scale, they do not perceive a great deal of a rivalry between students themselves $(\mathrm{M}=2.19, \mathrm{SD}=1.31)$, nor do they feel lonely in their study or research $(M=2.48, S D=1.52)$.

Table 2. Perception of climate in research work in postgraduate study on a seven-level assessment scale.

\begin{tabular}{|c|c|c|c|}
\hline Components of research climate & $N$ & $M$ & $S D$ \\
\hline Independence & 32 & 6.22 & 0.91 \\
\hline Opportunity for discussion & 32 & 5.94 & 1.01 \\
\hline Rivalry $^{*}$ & 32 & 2.19 & 1.31 \\
\hline Dependence $^{*}$ & 32 & 3.12 & 1.34 \\
\hline Own competence & 32 & 5.50 & 0.84 \\
\hline Excessive demands of study ${ }^{*}$ & 32 & 3.44 & 1.39 \\
\hline Positive encouragement for research & 32 & 5.44 & 1.41 \\
\hline Support in research & 32 & 5.38 & 1.52 \\
\hline Creativity & 32 & 5.10 & 1.01 \\
\hline Time pressure ${ }^{*}$ & 32 & 4.72 & 1.63 \\
\hline Cooperation & 32 & 5.53 & 127 \\
\hline Motivation & 32 & 6.06 & 1.01 \\
\hline Loneliness $^{*}$ & 32 & 2.48 & 1.52 \\
\hline Stress $^{*}$ & 32 & 3.84 & 1.82 \\
\hline Satisfaction & 32 & 5.25 & 116 \\
\hline Trust & 32 & 5.53 & 1.32 \\
\hline Intellectual challenges & 32 & 6.00 & 0.92 \\
\hline Tolerance & 32 & 5.45 & 1.15 \\
\hline Relaxed atmosphere & 32 & 5.31 & 1.12 \\
\hline
\end{tabular}

Note. ${ }^{\star}$ Demotivating components of climate. The statistics for the components that received the highest assessment are presented in bold type.

\section{Opportunities for creativity in research}

Students judge that in general researchers can be creative in all phases of the research process $\left(\mathrm{M}_{\text {average }}=3.91\right)$. In their opinion, researchers can best express their creativity in the execution of research $(\mathrm{M}=4.41, \mathrm{SD}=0.76)$ and in the definition of the research problem $(\mathrm{M}$ $=4.34, \mathrm{SD}=0.86$ ), while students attribute the least opportunity for creativity in research in the processing of data $(\mathrm{M}=3.00, \mathrm{SD}=1.19)$, although this too receives an above average assessment (Table 3 ). 
Table 3. Assessment of opportunities for the creativity of researchers in the individual phases of research work, on a five-level assessment scale.

\begin{tabular}{|l|c|c|c|}
\hline Phase of research work & $\boldsymbol{N}$ & $\boldsymbol{M}$ & $\boldsymbol{S D}$ \\
\hline Definition of research problem & 32 & 4.34 & 0.86 \\
\hline Preparation of theoretical background & 32 & 3.22 & 1.13 \\
\hline Preparation of research method & 32 & 3.69 & 0.93 \\
\hline Execution of research & 32 & 4.41 & 0.76 \\
\hline Data analysis & 32 & 3.00 & 1.19 \\
\hline Presentation of results & 32 & 4.03 & 1.12 \\
\hline Discussion & 32 & 4.19 & 0.74 \\
\hline Preparation of conclusions & 32 & 4.25 & 0.80 \\
\hline Publishing of research work & 32 & 4.09 & 0.78 \\
\hline
\end{tabular}

\section{Perception of own creativity in everyday life}

On a five-level scale, students made a high assessment of their own creativity in everyday life $(\mathrm{M}=4.4, \mathrm{SD}=0.66)$ (Figure 1 ).

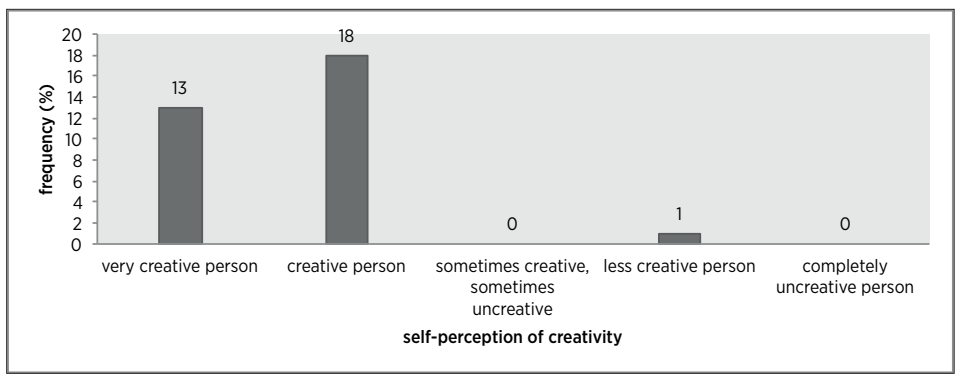

Figure 1. Assessment of own creativity in everyday life on a five-level assessment scale $(\mathrm{N}=32)$.

\section{Perception of originality in the area of own research}

Students see the central originality of their own research work in the definition of the research problem $(52 \%)$ and in the explanation of the research findings (48\%), and less frequently in the selection or definition of the research method (12\%). $16 \%$ of responses were classified in the category "other"; these are responses that appeared only once or in terms of content were impossible to combine into an individual category (e.g., the promotion of the work of hospital preschool teachers, the Roma question, preparation of a special programme) (Figure 2). 


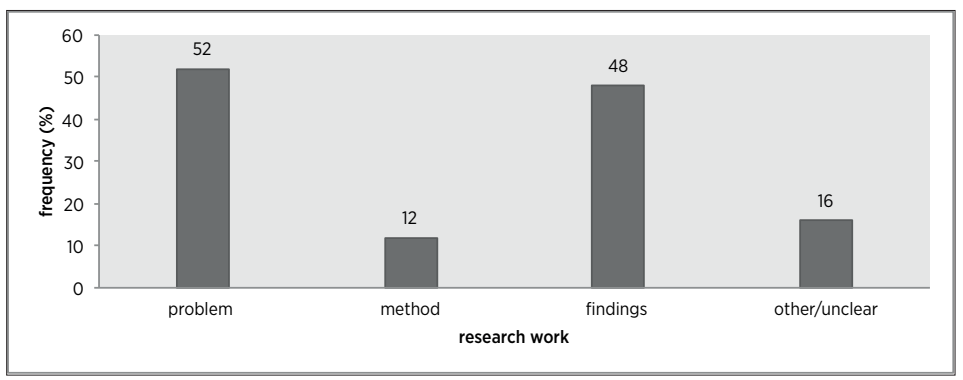

Figure 2. Perception of the central originality in own research work.

\section{Strategies for defining the problem and timeframe}

The results show (Figure 3 ) that in defining the research problem the majority of students (94\%) proceed primarily from their own professional experience and practice, $26 \%$ of students define the problem with the assistance of discussions with mentors and colleagues, while theoretical studies provide the basis for the definition of the problem for $22 \%$ of students; as a method for defining the problem, e-sources are used the least (3\%).

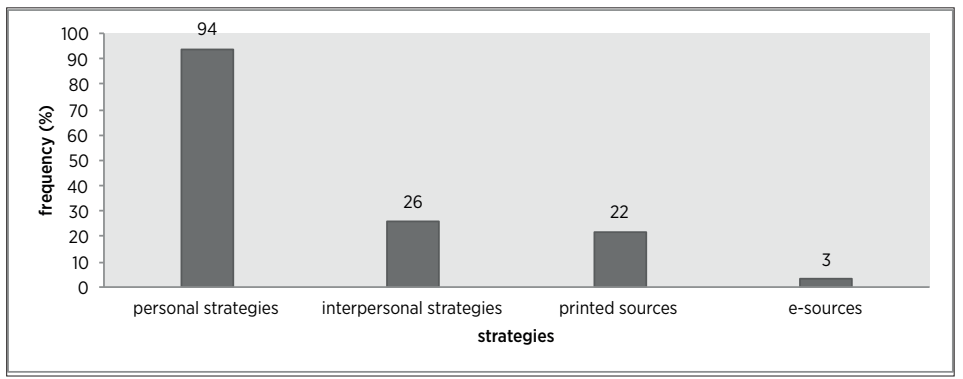

Figure 3. Strategies used for defining the research problem.

From the responses of students, it is possible to conclude that their perceptions of the time used to define the research problem are diverse (Figure 4). They stated that the time used in defining the problem ranged from a few hours to a few days (one week - 19\%), from several weeks to five months (one semester - 28\%) from the commencement of study to ten months (two semesters $-25 \%$ ), and a longer time, from the period prior to enrolment in postgraduate study or several years (one year or more $-16 \%$ ). Three students were completely unable to state a timeframe in which they defined the research problem: "It is very difficult for me to decide, as I surveyed various literature and at the same time considered a range of possibilities, therefore I cannot define this in time."; "It is difficult 
for me to define, because I have been dealing with the theme for many years."; "In fact, this theme has interested me for a long time".

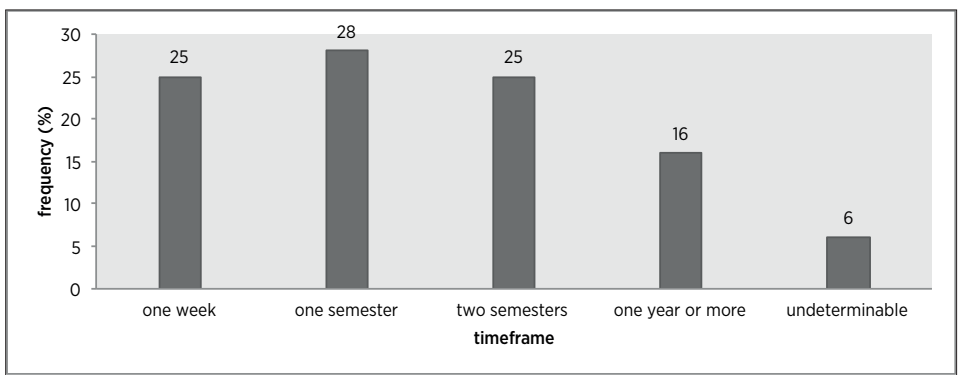

Figure 4. Timeframe for defining the research problem.

\section{Difficulties in defining the research problem}

Three students stated that they had no difficulties whatsoever in defining the research problem. The remaining students most frequently (46\%) encountered difficulty in giving meaning to the research through narrowing and elaboration of the research problem (i.e., the breadth, depth, specificity and application of the research, clearly designing research questions, establishing the hypothesis), as well as in finding relevant literature (14\%). The question of the actual (technical) feasibility of the research (10\%) was also emphasised as a difficulty, as well as time pressure of various kinds, such as the overburdening of the student due to work obligations and the short deadline for submitting the thesis $(8 \%)$, difficulties in communication with the mentor (8\%), and insufficient knowledge in the area of scientific writing (8\%) and research methodology (6\%) (Figure 5).

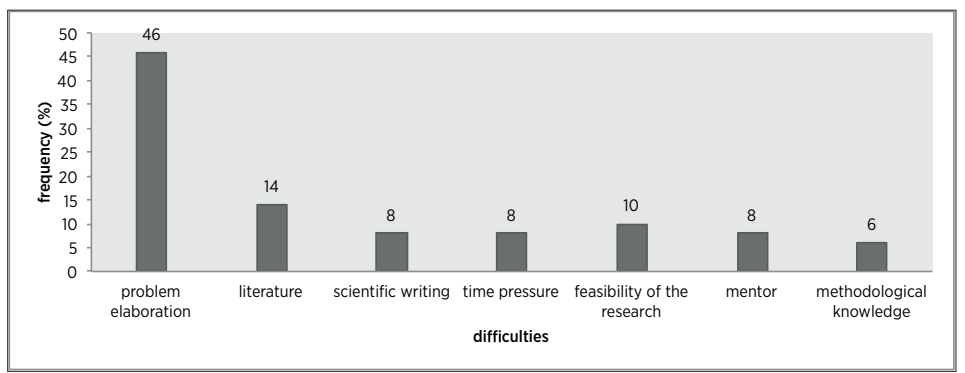

Figure 5. The perceived difficulties in defining the research problem. 


\section{Perceptions of the encouragement of mentors for the creative research of postgraduate students}

The most frequent form of encouragement perceived by students for creative work within the framework of research is general, less directive encouragement, in the sense of listening to the student, posing questions, discussions and general guidance in study and research (50\%). Students also perceive the mentor's encouragement of creative research work in the form of encouragement to study the literature (16\%), going into the problem and the research question in more depth (11\%) and the research method (11\%); later, encouragement is also perceived in the form of socialisational encouragement in the scientific-research space by enabling participation in conferences and collaboration in research projects $(5 \%)$, the use of the techniques creative thinking (e.g., brainstorming, target, carousel) (5\%) and with the mentor's own example - the mentor as a creative person ( $2 \%)$. The results according to the stated content categories are shown in Figure 6. In their responses, five students emphasised ineffective communication with the mentor, whether due to unsuccessful time coordination or the mentor's overburdening or absence, which was demotivating for the student regarding (creative) research work within the framework of postgraduate study. Two students did not provide an answer to this question.

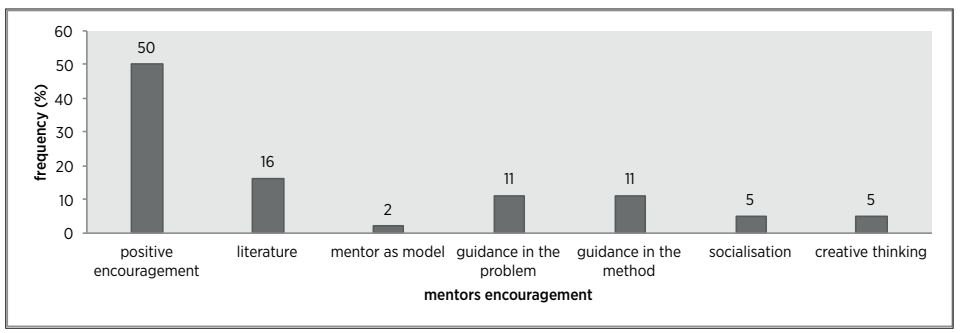

Figure 6. Perceptions of the mentors' encouragement of creative and innovative research work in postgraduate study.

\section{Discussion}

The purpose of the research was to study how postgraduate students perceive the opportunities for creative research in general, and how they perceive creativity in the preparation of their own research work in particular. The results show that students perceive a positive study-research climate that encourages creative processes, and that 
they believe that researchers can be creative in various phases of the research process (Amabile, 1996; Craig, 1990; Hemlin, Allwood \& Martin, 2004; Hennessay, 2006, Matelič, Mali \& Ferligoj, 2007). Students experience intense feelings of independence and motivation for their own research, as well as the intellectual stimulation of postgraduate study. They also give a high appraisal of other components that stimulate creative work - the possibility of discussion, the perception of one's own competences, the mentor's positive encouragement of research and support, cooperation, satisfaction, trust, tolerance and a relaxed atmosphere - while their appraisal of the components of rivalry, loneliness and dependence is much lower. On the basis of various empirical studies, Usher and Parker (2002) summarise similar contextual components that, in their opinion, have a significant influence on creativity in work groups; these components are work and tasks (independence, complexity, stress, etc.), social characteristics (communication, cooperation, etc.), and organisational characteristics (climate, organisation of work, etc.). All of these attributes are extremely important for the development of the inner motivation that researchers direct towards the process of research (cf. Adelson, 2003). Ryan and Deci (2000), authors of the Self-Determination Theory, explain that people are, by our very nature, proactive and oriented towards activities that satisfy three basic needs: the need for autonomy (the feeling that we manage ourselves and decide about ourselves), competence (the feeling that we are able to undertake or carry out a particular task) and relatedness (the feeling of being accepted by and connected to a broader social group). These needs condition the feeling of individual satisfaction, which in turn encourages tenacity and creative learning, as well as strengthening inner motivation. The significance of intrinsic motivation for the development of creativity is also emphasised by other authors (e.g., Amabile, 1996; Sternberg \& Lubard, 1996), but of particular importance is the contribution by Csikszentmihalyi (1999), for whom there is no creativity without motivation. Csikszentmihalyi explains the role of intrinsic motivation in creative work in his Flow Theory, in which he defines "flow" as "optimal experience", that is, the central motivational characteristic: "A sense that one's skills are adequate to cope with the challenges at hand in a goal directed, rule bound action system that provides clear clues as to how one is performing. Concentration is so intense that there is no attention left over to think about anything irrelevant or to worry about problems. Self-consciousness disappears, and the sense of time becomes distorted. An activity that produces such experiences 
is so gratifying that people are willing to do it for its own sake, with little concern for what they will get out of it, even when it is difficult or dangerous." (Csikszentmihalyi, 1991, p.71). It is also possible to explain the findings of Adelson (2003) from the perspective of "flow" experience when she states that first class scientists use a great deal of time for their research work and are unable to define this time precisely as they are practically constantly (as well as unconsciously) engaged with the problems that they are researching, that is, that they experience intrinsic motivation for their research. The results of the present study also show that most postgraduate students deal with their research problem for an extended period of time and that they experience intrinsic motivation for their research. This is further supported by the fact that the majority of the students "seek" their research problem in their own work experience, and that in seeking their research problem they most frequently use a "personal strategy" (Leong and Pfaltzgraff, 1996). In view of the responses, it is possible to conclude that in the forming their research problem students are guided by the "sense" or "usefulness" of the problem with regard to the goal of gaining a deeper knowledge of their own (educational) practice or of modifying this practice, and thus form the research problem on the basis of acquired work experience. Considering the age of the test subjects, it is possible to presume that they have an average of ten years of work experience; according to various authors (cf. Levin, 2008), work experience of this extent coincides with a decentration of thinking, that is, with a conceptual shift from thinking about one's own professional role to thinking about educational practice and the various participants in and users of this practice. According to the responses to the questions in our research, it is with these problems that the participating postgraduate students are engaged. An important question that therefore remains open for the moment is that of the actual originality of the research problems and their expected "solutions" by students in the broader scientific research sphere. Creativity in research is conditioned by the extensive knowledge ("mastery of the subject") that is the gained by studying the relevant literature (Leong \& Pfaltzgraff, 1996); however, the students report that only rarely do they use the strategies of printed or ICT sources. Furthermore, they also cite a range of difficulties in defining the research problem (difficulties in narrowing and perfecting the problem, in forming the research questions, in the research methodology), which can be attributed also to the development of the research idea, that is, the period between "preparation" and "information" (Cropley, 
2009). For this reason, this set of findings is particularly telling for the academic institution, indicating the sense in supporting students in the use of various study strategies in order to achieve the most effective possible elaboration of the research problem (cf. Cropley, 2009; Flippo \& Caverly, 2009). In addition to learning strategies for encouraging creativity in higher education, Candy, Crebert in O'Leary (1994, cited in Cropley, 2009) also suggest more systematic encouragement of the development of a research mental attitude (curiosity, critical thinking, self-regulation of learning), the mastery of the specific content area and of broader connections with other areas, information literacy (from searching for information to its use), and "personal urgency" linked with a good self-concept in the area of research. To this list, Craig (1990) adds a series of techniques for encouraging creative thinking, with which it is possible to stimulate creativity in research in all of the aforementioned areas. In addition, he highlights the principle of gradualness, as it is unrealistic to expect that on taking on their new role young researchers will suddenly or automatically become independent thinkers and/or creative problem solvers, insofar as in their learning history they were only encouraged to convergent thinking (seeking the one correct solution) without (many) opportunities for research learning and problem solving and innovation.

Half of all of the answers given by the students in connection with the question of the support of mentors in their creative research work are linked with the mentor's less directive communication style - the mentor in the role of someone who listens, encourages, poses questions. The mentor has an extremely important role in the career of the beginner researcher, especially in the period when the researcher is in his or her most creative years; Matelič, Mali and Ferligoj (2007) report that the mentor's scientific excellence and his or her attitude towards the person being mentored has an influence on the success of young researchers, and that "imposing an opinion too frequently, directing the course of the project in a way that is too detailed and limiting freedom in the selection of the content of the research reduces, and quite frequently even destroys, creativity, and with this the success of the researcher" (p. 92). From this perspective, given the results of the present study it is possible to conclude that students typically gain quality encouragement for their creative research from their mentors; however, at the same time the presence of certain cases of poor dyadic communication suggests that within the framework of the organisation of postgraduate study it would in the future be sensible to research 
the area of the social and organisational components of the study context in more detail (cf. Usher \& Parker, 2002) and to encourage these components in a more planned way (Hemlin, Allwood \& Martin, 2004). A culture that supports creative processes in a particular scientific research environment contributes significantly to the creativity of research groups, i.e., to the formation of creative interests, to the level and types of creativity (Hennessay, 2006; Yusuf, 2009). In connection with this, Neumann (2009) explains that "the best conditions for scientific creativity come with a free-flowing hierarchy and a highly developed culture of interaction to guarantee the exchange of ideas and inspiration. Furthermore, interdisciplinary interactions lead to the generation of new and unusual ideas. Finally, because of the freedom to try new things, these ideas can be tested and eventually generate new insights." (p. 205).

The question that arises from this discourse reopens the problem of the "architecture" of the existing system of postgraduate study (Zgaga, 2007), particularly with regard to its multitudinousness; this can be an obstacle to quality communication, which can in turn make it more difficult to differentiate between "excellent" and "average" academic products, and especially creative products. As Hermans (2011), the EU Directorate General for Research and Innovation, emphasised at the EU Conference on Talent Support, in the document "Europe 2020 Strategy" emphasis is placed on the responsibility of EU members to encourage the creative and innovative cooperative work of young researchers both on the level of postgraduate study and in the area of their employment, with the goal of strengthening the intellectual and social capital of the EU for sustainable development and for increasing competition in world markets.

The fact is that in contemporary society knowledge, whose key element is creativity, is becoming an increasingly valuable commodity both in the area of research and its products and as well as in the application of knowledge, in the sense of various types and forms of innovation. The academic micro-environment is undoubtedly one of the most important "generators" of creative ideas (Cropley, 2009; Gulbrandsen, 2004; Hollingsworth, 2007), while at the same time being a "sensor" for recognising creative young researchers who are highly sensitive to research problems - they know how to find good research problems, they recognise concealed research problems and they invent new research problems - as well as possessing other personality characteristics (sufficient flexibility, openness, independence, preparedness 
to take risks, etc.) that condition creative research and the achievement of scientific results. For this reason, it is critical that the academic institution provide students with a creative environment, offering them mentors who, in addition to research competences in the narrow sense, also encourage students to develop a value system in the context of scientific creativity.

\section{References}

Adelson, B. (2003). Issues in scientific creativity: insight, perseverance and personal technique: Profiles of the 2002 Franklin institute laureates. Journal of Franklin Institute, 340, 163-189.

Amabile, T. M. (1996). Creativity in context: Update to the social psychology of creativity. Boulder, CO: Westview Press.

Amabile, T. M., Conti, R., Coon, H., Lazenby, J., \& Herron, M. (1996). Assessing the work environment for creativity. Academy of Management Journal, 39, 1154-1184.

Beghetto, R. A., \& Kaufman, J. C. (2007). Toward a broader conception of creativity: A case for "mini-c" creativity. Psychology of Aesthetics, Creativity, and the Arts, 1, 73-79. doi: 10.1037/1931-3896.1.2.73

Charyton, C., \& Snelbecker, G. E. (2007). General, artistic and scientific creativity attributes of engineering and music students. Creativity research Journal, 19, 213-225. Csikszentmihalyi, M. (1991). Flow: The psychology of optimal experience. New York, NY: Harper \& Row.

Chikszentmihalyi, M. (1999). Implications of a systems perspective for the study of creativity. In R. J. Sternberg (Ed.), Handbook of creativity (pp. 313-335). New York, NY:

Cambridge University Press.

Collins, R. (2007). The creativity of intellectual networks and the struggle over attention space. In A. Sales, \& M. Fournier (Eds.), Knowledge, communication and creativity (pp. 156-165). London: Sage.

Craig, L. (1990). A guide to increased creativity in research - inspiration or perspiration?

Roundtable. Bioscience, 40, 123-129.

Ekvall, G. (1996). Organizational climate for creativity and innovation. European Journal of Work and Organizational Psychology, 5, 105-123.

Flippo, R. F., \& Caverly, D. C. (Eds.) (2009). Handbook of college reading and study strategies research ( $2^{\text {nd }}$ ed). New York, NY: Routledge.

Furnham, A., \& Bachtiar, V. (2008). Personality and intelligence as predictors of creativity. Personality and Individual Differences, 45, 613-617.

Gardner, H. (2003). Razsežnosti uma: Teorija o več inteligencah. Ljubljana: Tangram.

Guilford, J. P. (1950). Creativity. American Psychologist, 5, 444-454.

Gulbrandsen, M. (2004). Accord or discord? Tensions and creativity in research. In S.

Hemlin, C. M. Allwood, \& B. R. Martin (Eds.), Creative knowledge environments: The 
influences on creativity in research and innovation (pp. 31-57). Cheltenham: Edward Elgar. Heinze, T., Shapira, P., Rogers, J. D., \& Senker, J. M. (2009). Organizational and institutional influences on creativity in scientific research. Research Policy, 38, 610-623. Heinze, T., Shapira, P., Senker, J. M., \& Kuhlmann, S. (2007). Identifying creative research accomplishments: Methodology and results for nanotechnology and human genetics.

Scientometrics, 70, 125-152.

Hemlin, S. (2009). Creative knowledge environments: An interview study with members and group leaders of university and industry $R \& D$ groups in biotechnology. Creativity and Innovation management, 18, 278-285. doi: 10.1111/j.1467-8691.2009.00533.x.

Hemlin, S., Allwood, C. M., \& Martin, B. R. (2004). What is creative knowledge environments? In S. Hemlin, C. M. Allwood, \& B. R. Martin (Eds.), Creative knowledge environments: The influences on creativity in research and innovation (pp. 1-30).

Cheltenham: Edward Elgar.

Hennessay, B. A. (2006). Creativity and motivation in the classroom: A social psychological and multi-cultural perspective. In A. G. Tan (Ed.), Creativity: A handbook for teachers (pp. 27-46). Singapore: World Scientific.

Hermans, S. (2011). Creativity and innovation in the EU 2020 strategy. Plenary speech at Hungarian EU Presidential Conference on Talent Support and First European Talent Day, Budapest, 7.-9.4.2011.

Hunter, S. T., Bedell, K. E., \& Mumford, M. D. (2007). Climate for creativity: A quantitative review. Creativity Research Journal, 19, 69-90.

L’Abate, L., DeGiacomo, P., Capitelli, M., \& Longo, S. (Eds.) (2009). Science, mind and creativity: The Bari symposium. New York, NY: Nova Science Publishers.

Leong, F. T. L., \& Pfaltzgraff, R. E. (1996). Finding the research topic. In F. T. L. Leong, \& J. T. Austin (Eds.), The psychology research handbook: A guide for graduate students and research assistants (pp. 3-17). Thousand Oaks, CA: Sage.

Levin, B. B. (2008). Case studies of teacher development: An in-depth look at how thinking about pedagogy develops over time. Taylor \& Francis e-Library.

Makel, M. C., \& Plucker, J. A. (2008). Creativity. In S. I. Pfeiffer (Ed.), Handbook of giftedness in children: Psychoeducational theory, research, and best practices (pp. 247-270).

New York, NY: Springer.

Matelič, U., Mali, F., \& Ferligoj, A. (2007). Kreativno okolje in uspešnost mladih raziskovalcev. Družboslovne razprave, 23, 71-94.

Miller, A. I. (2000). Insights of genius: Imagery and creativity in science and art. New York, NY: First MIT Press.

Neumann, C. J. (2009). Fostering creativity: A model for developing a culture of collective creativity in science. EMBO reports, 8, 202-206.

Ochse, R. (1990). Before the gates of excellence. The determination of creative genius.

Cambridge: Cambridge University Press.

Pečjak, V. (1987). Misliti, delati, živeti ustvarjalno. Ljubljana: Državna založba Slovenije. 
Plucker, J., Beghetto, R. A., \& Dow, G. T. (2004). Why isn't creativity more important to educational psychologists? Potentials, pitfalls, and future directions in creativity research.

Educational Psychologist, 39, 83-96. doi: 10.1207/s15326985ep3902_1

Runco, M. (2004). Creativity. Annual Review of Psychology, 55, 657-687.

Sawyer, R. K. (2006). Explaining creativity: The science of human innovation. New York,

NY: Oxford University Press.

Ryan, R. M., \& Deci, E. L. (200o). Intrinsic and extrinsic motivations: Classic definitions and new directions. Contemporary Educational Psychology, 25, 54-67.

Simonton, D. K. (2003). Scientific creativity as constrained stochastic behaviour: The integration of product, person, and process perspectives. Psychological Bulletin, 129,

475-494. doi: 10.1037/0033-2909.129.4.475

Simonton, D. K. (2004). Creativity in science: Chance, logic, genius, and zeitgeist.

Cambridge: Cambridge University Press.

Soler, J. M. (2007). A rational indicator of scientific creativity. Journal of Infometrics, 1 , $123-130$.

Stehr, N. (1994). Knowledge Societies. Sage: London.

Sternberg, R. J. (2003). Wisdom, intelligence, and creativity synthesized. Cambridge:

Cambridge University Press.

Sternberg, R. J., \& Lubart, T. I. (1996). Investing in creativity. American Psychologist, 51, $677-688$.

Sternberg, R. J., \& Lubard, T. I. (1999). The concept of creativity: Prospects and paradigms. In R. J. Sternberg (Ed.), Handbook of creativity (pp. 3-15). Cambridge: Cambridge University Press.

Unsworth, K. L., \& Parker, S. K. (2002). Promoting a pro-active and innovative workforce for the new workplace. In D. Holman, T.D. Wall, C. W. Clegg, P. Sparrow, \& A. Howard (Eds.), The New Workplace: A Guide to the Human Impact of Modern Work Practices (pp. 175-196). Chichester: John Wiley \& Sons.

Urban, K. K. (2007). Assessing creativity: A componential model. In A. G. Tan (Ed.),

Creativity: A handbook for teachers (pp. 167-186). Singapore: World Scientific.

Weisberg, R. W. (1993). Creativity: Beyond the myth of genius. New York, NY: Freeman and Company.

Zgaga, P. (2007). »Bolonjska arhitektura« doktorskega študija? Nekatere ključne teme v novejših razpravah o doktorskem študiju v Evropi. Vestnik - Univerza v Ljubljani, 38, 3-7. Yusuf, S. (2009). From creativity to innovation. Technology and Society, 31, 1-8. doi: 10.1016/j.techsoc.2008.10.007 


\section{Biographical note}

MoJCA JurišEvič is an Assistant Professor in Educational Psychology at University of Ljubljana, Faculty of Education. Her research interests lie in personality factors which influence learning processes, primarily motivation for learning. She is involved in many national and international research projects on this topic. Professionally she works closely with teachers in pre-service and in-service teacher training, especially through situational learning and teacher's portfolios development. She is a member of the National Expert Commission for Educating the Gifted and Talented. 